\title{
Determinants of blood eosinophil levels in the general population and patients with COPD: a population-based, epidemiological study
}

\author{
Marc Miravitlles ${ }^{1,2^{*}}$ (D), Juan José Soler-Cataluña ${ }^{2,3}$, Joan B. Soriano ${ }^{2,4}$, Francisco García-Río 2,5, \\ Pilar de Lucas ${ }^{6}$, Inmaculada Alfageme , Ciro Casanova ${ }^{8}$, José Miguel Rodríguez González-Moro ${ }^{9}$, \\ M. Guadalupe Sánchez-Herrero ${ }^{10}$, Julio Ancochea ${ }^{2,4}$ and Borja G. Cosío 2,11
}

\begin{abstract}
Background: Blood eosinophils are considered a biomarker for the treatment of chronic obstructive pulmonary disease (COPD). Population-based studies are needed to better understand the determinants of the blood eosinophil count (BEC) in individuals with and without COPD.

Methods: EPISCAN II is a multicentre, cross-sectional, population-based epidemiological study aimed at investigating the prevalence and determinants of COPD in Spain. Study subjects were randomly selected from the general population, and COPD was defined by a post-bronchodilator $F E V_{1} / F V C<0.7$. For the pre-specified outcomes related to BEC, the first 35 COPD and 35 non-COPD subjects were consecutively recruited in 12 of the participating centres with the objective of analysing 400 individuals in each group. Baseline BEC and its association with demographic, clinical and functional variables were analysed.

Results: A total of 326 COPD and 399 non-COPD subjects were included in the analysis. The mean age (standard deviation [SD]) was 63.2 years (11.0), 46.3\% were male, and $27.6 \%$ were active smokers. BEC was significantly higher in

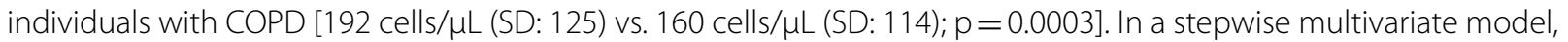
being male, active smoker and having a previous diagnosis of asthma were independently associated with having a higher BEC.
\end{abstract}

Conclusions: This population-based study estimated the distribution of eosinophils in the healthy adult population and concluded that COPD patients have a significantly higher BEC. Male sex, active smoking and concomitant asthma were significantly associated with a higher BEC.

Keywords: Epidemiology, Computed tomography, Imaging population, Biomarkers

\footnotetext{
*Correspondence: marcm@separ.es

${ }^{1}$ Pneumology Department, Hospital Universitari Vall d'Hebron/Vall

d'Hebron Institut de Recerca (VHIR), Vall d'Hebron Barcelona Hospital

Campus, P. Vall d'Hebron 119-129, 08035 Barcelona, Spain

Full list of author information is available at the end of the article
}

\begin{abstract}
Background
Chronic obstructive pulmonary disease (COPD) is a heterogeneous disease with multiple phenotypes and endotypes, which may be associated with different prognoses and response to treatment $[1,2]$. One of the most widely studied phenotypes of COPD is that associated with increased eosinophilic inflammation. Although there is
\end{abstract} original author(s) and the source, provide a link to the Creative Commons licence, and indicate if changes were made. The images or other third party material in this article are included in the article's Creative Commons licence, unless indicated otherwise in a credit line to the material. If material is not included in the article's Creative Commons licence and your intended use is not permitted by statutory regulation or exceeds the permitted use, you will need to obtain permission directly from the copyright holder. To view a copy of this licence, visit http://creativecommons.org/licenses/by/4.0/. The Creative Commons Public Domain Dedication waiver (http://creativeco mmons.org/publicdomain/zero/1.0/) applies to the data made available in this article, unless otherwise stated in a credit line to the data. 
still controversy about the role of the blood eosinophil count (BEC) as a marker of risk of exacerbation [3-8], there is wide consensus about the role of the BEC as a biomarker to identify patients who will present better response to inhaled corticosteroids (ICS) [9-11]. In fact, the most recent recommendations of pharmacologic treatment include the BEC as a guide for the indication of treatment with ICS, particularly in patients at risk of exacerbations $[12,13]$.

In order to better understand the role of blood eosinophils as a biomarker in COPD it is important to generate new data about the distribution of blood eosinophil values in healthy adult populations and different groups of patients with COPD according to different phenotypes, degree of severity and treatments. While the distribution of blood eosinophils has been examined in several United States $[3,14]$ or North and Central Europe-based COPD populations [14-18], data from Southern European countries are limited.

EPISCAN II is a population-based, epidemiological study the main objective of which was to investigate the prevalence and determinants of COPD in all autonomous communities in Spain [19]. One of the pre-specified secondary objectives of the EPISCAN II study was to analyse the distribution of BECs in a subsample of participants with and without COPD in order to estimate BECs in the general adult Spanish population and to investigate factors associated with an elevated BEC [19]. The current article presents the results of the analysis of BECs and their determinants in a subgroup of participants in the EPISCAN II study with and without COPD from centres distributed throughout Spain.

\section{Methods}

EPISCAN II is a national, multicentre, cross-sectional, population-based epidemiological study the main objective of which was to investigate the prevalence of COPD in Spain. The full protocol, the fieldwork and all the methods have been described previously $[19,20]$. Briefly, 20 hospitals from the 17 Spanish autonomous communities conducted the study from April 2017 to February 2019. Subjects from the general population who were resident in the postal code areas nearest the participating hospitals were selected. A list of random telephone numbers was obtained, stratified according to these postal codes and quotas for sex and age groups. The inclusion criteria were as follows: men or women aged 40 years or more with no physical or cognitive difficulties that would prevent them from completing spirometry or any of the study procedures.
The study was approved by the ethics committees of each of the participating centres, and all participants provided informed consent. The EPISCAN II protocol is registered at https://clinicaltrials.gov (NCT03028207) and at www.gsk-clinicalstudyregister.com/study/205932.

\section{Variables and procedures}

Demographic information on age, sex, level of education, family conditions, comorbidities, weight, height and smoking were collected. The number of respiratory exacerbations in the last 12 months was also collected. Forced spirometry was performed using a pneumotachograph (Vyntus Spiro, Carefusion, Germany), according to standardized procedures [21], and Global Lung Function Initiative equations were used as the reference value [22]. Spirometry was performed before and 15-30 min after inhalation of $400 \mu \mathrm{g}$ of salbutamol. COPD was defined as a post-bronchodilator forced expiratory volume in one second/forced vital capacity $\left(\mathrm{FEV}_{1} / \mathrm{FVC}\right)$ ratio $<0.7$. The study population was divided into two cohorts, depending on the results of the post-bronchodilator spirometry: patients with COPD $\left(\mathrm{FEV}_{1} / \mathrm{FVC}<0.7\right)$ and non-COPD individuals $\left(\mathrm{FEV}_{1} / \mathrm{FVC} \geq 0.7\right)$. Symptoms were assessed by the COPD Assessment Test (CAT) questionnaire. Physical activity was measured by the Yale Physical Activity Questionnaire (YPAS) validated for the Spanish population and the elderly population. This questionnaire reflects the amount, frequency, and intensity of physical activity that can be used to estimate the effects of physical activity as a continuous parameter, even at the low levels of activity that might be expected in COPD patients $[23,24]$. The 6 -min walking test $(6 \mathrm{MWT})$ was performed according to the American Thoracic Society (ATS) guidelines [25].

Absolute values and percentage of diffusing capacity of the lung for carbon monoxide (DLCO) and alveolar volume were collected by single-breath $\mathrm{CO}$ diffusing capacity (MasterScreen diffusion, Carefusion, Germany), according to the ATS/European Respiratory Society (ERS) recommendations [26]. Twenty $\mathrm{ml}$ of venous blood were collected from each participant for routine blood analysis, and determination of C-reactive protein (CRP) and fibrinogen. The collection procedure was standardised, and each centre stored the samples at $-80{ }^{\circ} \mathrm{C}$ until shipping for centralised analysis.

Computed tomography (CT) images were acquired during inhalation, without contrast and with lowdose radiation. The images obtained underwent semiautomatic post-processing for determination of the 
percentage of emphysema, areas of extension, airway thickness, and other lung parenchyma attenuation and airway wall thickness parameters [27-29].

\section{Statistical analysis}

Considering the $10.2 \%$ prevalence of COPD found in the previous EPISCAN study [28] a priori sample size calculation estimated that with an accuracy of $\pm 0.6 \%$ and a $10 \%$ dropout rate, approximately 10,200 eligible individuals should be included in the study for the primary outcome, that is, the prevalence of COPD in Spain. For secondary outcomes related to CT scan and blood analysis, the first 35 COPD and 35 non-COPD subjects were consecutively invited to participate in 12 of the participating centres with the objective of recruiting a total of approximately 400 individuals in each group. Categorical variables were presented as numbers with percentages, and continuous variables as mean with standard deviation (SD). The characteristics of the population in the diagnosis of COPD groups were compared using the Student's t-test, or $\chi^{2}$ test. The comparisons of blood eosinophil levels according to clinical, functional and $\mathrm{CT}$ characteristics were tested for significance using the Student's t-test and analysis of variance. Correlations between continuous variables were evaluated using Pearson's correlation coefficient. Univariate and multivariate linear regression analyses were used to investigate factors associated with blood eosinophil levels. Only variables with a level of significance $<0.1$ in the univariate analysis were included in a stepwise multivariate linear regression model. The R2 coefficient of determination was calculated for the model. Data were analysed with the Statistical Analysis System (SAS) Enterprise Guide 7.15, considering a statistical significance (p) of 0.05 for all the statistical tests performed.

\section{Results \\ Population}

The 12 participating centres recruited a total of 326 COPD and 399 non-COPD subjects, who constituted the population of our study. The mean age of the participants was 63.2 years (SD): 11.0 , and $46.3 \%$ were male, and $27.6 \%$ were active smokers. Most clinical characteristics were significantly different between COPD and nonCOPD participants. COPD subjects were older, more frequently male, less frequently never smokers, with lower lung function parameters, less exercise tolerance and higher CAT scores (Table 1).
Regarding blood analysis, COPD individuals had no significant differences in red blood cells, platelets, fibrinogen $(\mathrm{g} / \mathrm{L})$ or CRP $(\mathrm{mg} / \mathrm{dL})$ values but did have higher concentrations of total leukocytes, neutrophils and eosinophils $(\mathrm{p}<0.05)$ (Table 1$)$.

On CT imaging, COPD participants showed a higher percentage of areas of emphysema [10\% (11.9) vs. $4.7 \%$ (7.5); $\mathrm{p}<0.0001$ ] and higher percentages of airway wall area in both primary and secondary bronchi (both $\mathrm{p}<0.0001$ ) (Table 1).

\section{Blood eosinophil counts according to the different subject characteristics}

The mean BEC was 175 cells/ $\mu \mathrm{L}$ (SD: 120 ; $95 \%$ confidence interval [CI]: 166;184) and median 150 cells/ $\mu \mathrm{L}$. BECs were significantly higher in individuals with COPD (192 cells/ $\mu \mathrm{L}$ (SD: 125; median: 177 cells/ $\mu \mathrm{L}$ ) vs. 160 cells/ $\mu \mathrm{L}$ (SD: 114 ; median: 132 cells/ $\mu \mathrm{L}) ; \mathrm{p}=0.0003)$. The distribution of blood eosinophils in both groups of subjects is depicted in Fig. 1. There were no differences in the proportion of subjects with more than 300 eosinophils $/ \mu \mathrm{L}(11.5 \%$ in non-COPD vs. $16 \%$ in COPD, $\mathrm{p}=0.08$ ), but there were more non-COPD subjects with less than 100 eosinophils/ $\mu \mathrm{L}$ compared with COPD patients $(32.8 \%$ vs. $20.6 \%, p=0.0002)$. In the 159 subjects with airflow obstruction according to the lower limit of normal of FEV1/FVC the mean BEC was 204 cells/ $\mu \mathrm{L}$ (SD: 135; 95\% confidence interval $[\mathrm{CI}]: 182 ; 225)$ and median 180 cells $/ \mu \mathrm{L}$. BECs were also significantly higher in men, smokers, individuals with more advanced stages of COPD and in those with a previous diagnosis of asthma.

The differences in BEC according to $\mathrm{CT}$ scan parameters did not achieve statistical significance (Table 2). This analysis was repeated separately for the COPD patients and the non-COPD participants, and neither subgroup showed significant differences in BEC between individuals with or without significant emphysema or airway thickness (data not shown). Since the majority of the COPD patients identified were mild, we changed the cut off of emphysema from 10 to $5 \%$, but again no significant differences in BEC were observed (189.5 cells $/ \mu \mathrm{L}$ (SD: 134.2$)$ in patients with 0-5\% emphysema compared to 202.8 cells $/ \mu \mathrm{L}$ (SD: 129.1) in patients with $>5 \%$ emphysema; $\mathrm{p}=0.18$ ).

Figure 2 shows the mean and 95\%CI of blood eosinophil levels in the different subgroups of participants classified according to the variables showing significant differences in univariate analysis. 
Table 1 Demographic, clinical, blood, and imaging characteristics of participants according to the presence of airflow limitation compatible with COPD

\begin{tabular}{|c|c|c|c|c|}
\hline & $\operatorname{COPD}(n=326)$ & Non-COPD $(n=399)$ & All $(n=725)$ & P value \\
\hline \multicolumn{5}{|l|}{ Demographic } \\
\hline Age, years & $66.9(10.5)$ & $60.1(10.5)$ & $63.2(11.0)$ & $<0.0001$ \\
\hline Sex, male, \% & $182(55.8 \%)$ & $154(38.6 \%)$ & $336(46.3 \%)$ & $<0.0001$ \\
\hline BMI & $27.1(4.4)$ & $27.1(4.8)$ & $27.1(4.6)$ & 0.986 \\
\hline Smoker & 114 (35.0\%) & $86(21.6 \%)$ & $200(27.6 \%)$ & $<0.0001$ \\
\hline Former smoker & $151(46.3 \%)$ & $152(38.1 \%)$ & $303(41.8 \%)$ & \\
\hline Never smoker & $61(18.7 \%)$ & $161(40.4 \%)$ & $222(30.6 \%)$ & \\
\hline \multicolumn{5}{|l|}{ Clinical } \\
\hline Asthma diagnosis & $42(12.9 \%)$ & $32(8.0 \%)$ & $74(10.2 \%)$ & 0.031 \\
\hline CAT & $9.2(6.9)$ & $7.0(5.9)$ & $8.0(6.5)$ & $<0.0001$ \\
\hline $\mathrm{FEV}_{1}, \mathrm{~L}$ & $2.2(0.7)$ & $2.9(0.7)$ & $2.6(0.8)$ & $<0.0001$ \\
\hline $\mathrm{FEV}_{1}, \%$ & $82.0(18.7)$ & $104.6(14.6)$ & $94.4(20.0)$ & $<0.0001$ \\
\hline DLCO, \% & $89.9(23.1)$ & $98.8(18.4)$ & $94.8(21.1)$ & $<0.0001$ \\
\hline $\mathrm{FEV}_{1} / \mathrm{FVC}$ & $62.0(8.4)$ & $79.8(5.1)$ & $71.8(11.1)$ & $<0.0001$ \\
\hline $6 \mathrm{MWD}, \mathrm{m}$ & $478(108)$ & $518(98)$ & $501(105)$ & $<0.0001$ \\
\hline YPAS, score & $45.7(23.1)$ & $48.4(21.6)$ & $47.2(22.3)$ & 0.111 \\
\hline Exacerbations last year & $0.27(0.82)$ & $0.05(0.27)$ & $0.14(0.60)$ & $<0.0001$ \\
\hline Treatment with ICS & $61(18.7 \%)$ & $16(4.0 \%)$ & $77(10.6 \%)$ & $<0.0001$ \\
\hline \multicolumn{5}{|l|}{ Blood } \\
\hline Erythrocyte, cells/ $\mu$ l & $4.95(0.52)$ & $4.92(0.44)$ & $4.93(0.47)$ & 0.796 \\
\hline 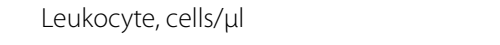 & 7273 (2194) & $6746(1838)$ & $6983(2022)$ & 0.0005 \\
\hline 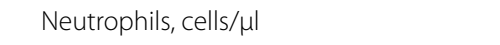 & $4284(1603)$ & 3925 (1426) & $4086(1518)$ & 0.001 \\
\hline Neutrophils, \% & $58.5(9.2)$ & $57.3(8.3)$ & $57.9(8.8)$ & 0.068 \\
\hline Eosinophils, cells/ $\mu$ l & $192(125)$ & $160(114)$ & $175(120)$ & 0.0003 \\
\hline Eosinophils $<100$ cell/ $\mu \mathrm{L}$ & $67(20.6 \%)$ & $131(32.8 \%)$ & $198(27.3 \%)$ & 0.0002 \\
\hline Eosinophils $>300$ cells/ $\mu \mathrm{L}$ & $52(16.0 \%)$ & $46(11.5 \%)$ & $98(13.5 \%)$ & 0.080 \\
\hline Eosinophils, \% & $2.8(1.8)$ & $2.4(1.6)$ & $2.6(1.7)$ & 0.008 \\
\hline Platelets, cells/ $\mu$ l & $233(58)$ & $241(62)$ & $238(61)$ & 0.070 \\
\hline Fibrinogen ( $g / L)$ & $3.9(0.9)$ & $3.8(0.9)$ & $3.8(0.9)$ & 0.208 \\
\hline $\mathrm{CRP}(\mathrm{mg} / \mathrm{dL})$ & $2.0(4.1)$ & $1.5(2.8)$ & $1.7(3.4)$ & 0.0514 \\
\hline \multicolumn{5}{|l|}{ Imaging } \\
\hline Emphysema, \% & $10.0(11.9)$ & $4.7(7.5)$ & $7.0(10.0)$ & $<0.0001$ \\
\hline Airway wall area, \% (Primary bronchi) & $18.4(2.9)$ & $16.9(3.4)$ & $17.6(3.3)$ & $<0.0001$ \\
\hline Airway wall area, \% (Secondary bronchi) & $27.5(5.7)$ & $24.6(5.6)$ & $25.9(5.8)$ & $<0.0001$ \\
\hline
\end{tabular}

$B M I$ body mass index, CAT COPD assessment test, FEV1 forced expiratory volume in the first second, FVC forced vital capacity, DLCO diffusion capacity of the lung for carbon monoxide, 6MWD 6-min walk distance, YPAS Yale Physical Activity Questionnaire, CRP C-reactive protein

\section{Factors independently associated with BEC}

A stepwise multivariate model was developed with the following variables: age, sex, body mass index, smoking, previous diagnosis of asthma, COPD, CAT scores, FEV1 (\%), DLCO (\%), YPAS score, 6MWD, exacerbations,
ICS treatment, platelets, fibrinogen, CRP, emphysema (\% fixed threshold), and airway wall area (for central and peripheral airways in \%). Only five variables had a $p$ value $<0.10$ in the final model, with three being significant at a level of $<0.05$. Being male, active smoker, and having a previous diagnosis of asthma were significantly 


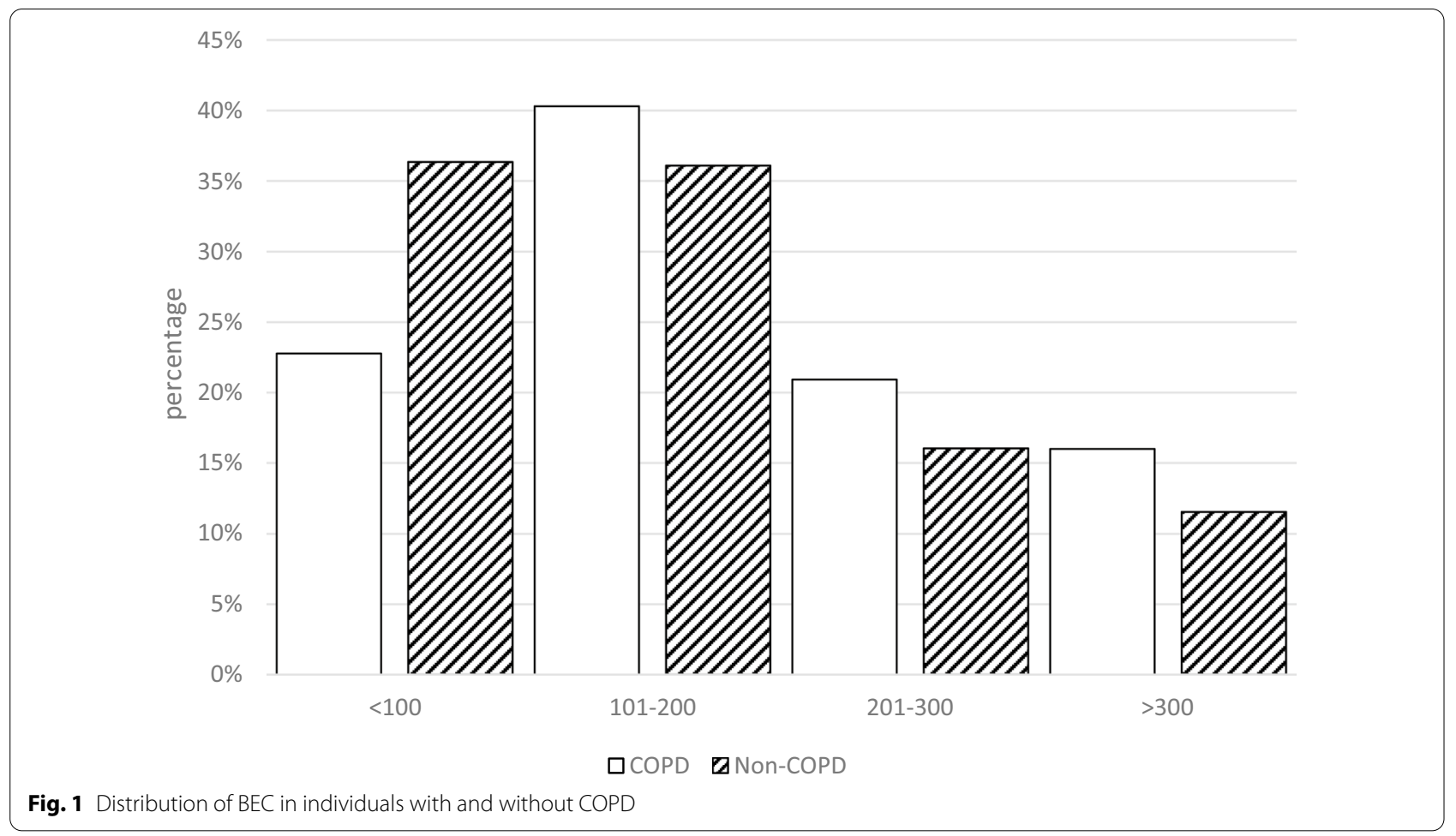

and independently associated with a higher BEC (Table 3).

\section{Discussion}

Given the potential for BEC as a biomarker in COPD $[9,11,30]$, it is important to understand the distribution and determinants of BEC in the general adult population and in COPD patients. Our population-based sample of non-COPD adults recruited in the EPISCAN II study had a mean BEC of 160 cells/ $\mu \mathrm{L}$, being significantly higher for COPD patients. We also observed a significantly higher BEC in males, active smokers, and individuals with previous history of asthma and increased levels of eosinophils with increasing severity of airflow obstruction.

Since the EPISCAN II was a population-based epidemiological study, it is important to note that the majority of our population of COPD patients had mild disease, with $56 \%$ of GOLD stage I, and $75 \%$ were undiagnosed and untreated [20].

The mean BEC in non-COPD subjects was 160 cells/ $\mu \mathrm{L}$, which was significantly lower than the mean count in COPD patients (192 cells $/ \mu \mathrm{L})$. The concentrations observed in our population of non-COPD individuals were intermediate compared to those observed in an Austrian population described by Hartl et al. [17] with a geometric mean of 128 cells $/ \mu \mathrm{L}$, or those reported in a study in the UK $(140$ cells $/ \mu \mathrm{L}$ in smokers and 120 cells $/ \mu \mathrm{L}$ in non-smokers) [18], and the concentrations observed in the UK Clinical Practice Research Datalink (182 cells/ $\mu \mathrm{L})$ [15]. However, they were very similar to the values reported in Copenhagen, with a median value of 150 cells $/ \mu \mathrm{L}$ in adult never smokers and 160 cells $/ \mu \mathrm{L}$ in ever smokers [16].

Our data replicate previous results showing a significantly higher BEC in subjects with COPD compared with non-COPD controls. In the previously mentioned study by Kolsum et al. [18], the mean BEC was 209 cells $/ \mu \mathrm{L}$ in COPD subjects, and in the UK database study, blood eosinophils were a mean of $8 \%$ higher in COPD compared with non-COPD subjects [15]. A previous population-based database study in Spain in $+57,000$ patients with COPD reported a mean eosinophil count of 253 cells/ $\mu \mathrm{L}$ [5], with $28.4 \%$ 
Table 2 Blood eosinophil levels according to clinical, functional and $\mathrm{CT}$ characteristics

\begin{tabular}{|c|c|c|c|}
\hline & \multicolumn{2}{|l|}{ Blood eosinophil counts } & \multirow[t]{2}{*}{ P value } \\
\hline & Mean (SD) $(95 \% \mathrm{Cl})$ & $\mathbf{n}$ & \\
\hline \multicolumn{4}{|l|}{ Sex } \\
\hline Male & $194.8(127.7)(181.1 ; 208.5)$ & 336 & $<0.0001$ \\
\hline Female & $158.1(111.7)(147.0 ; 169.3)$ & 388 & \\
\hline \multicolumn{4}{|l|}{ Age } \\
\hline $40-50$ & $166.2(123.4)(139.9 ; 192.5)$ & 87 & 0.848 \\
\hline $50-60$ & $178.5(126.8)(161.1 ; 196.1)$ & 204 & \\
\hline $60-70$ & $173.0(118.6)(157.3 ; 188.8)$ & 219 & \\
\hline$>70$ & $177.7(116.4)(162.0 ; 193.4)$ & 214 & \\
\hline \multicolumn{4}{|l|}{ BMI } \\
\hline Underweight & $166.8(132.6)(44.2 ; 289.6)$ & 7 & 0.928 \\
\hline Normal & $171.7(136.8)(154.4 ; 189.0)$ & 243 & \\
\hline Overweight & $178.3(112.7)(165.6 ; 191.0)$ & 306 & \\
\hline Obese & $173.9(108.5)(157.2 ; 190.6)$ & 165 & \\
\hline \multicolumn{4}{|l|}{ Smoking } \\
\hline Smoker & $189.4(123.2)(172.2 ; 206.6)$ & 200 & 0.025 \\
\hline Former smoker & $178.1(123.3)(164.2 ; 192.1)$ & 303 & \\
\hline Never smoker & $158.2(113.1)(143.2 ; 173.2)$ & 221 & \\
\hline \multicolumn{4}{|l|}{ Asthma diagnosis } \\
\hline Yes & 204.5 (142.0) (171.6; 237.4) & 74 & 0.027 \\
\hline No & $171.8(117.7)(162.8 ; 180.9)$ & 650 & \\
\hline \multicolumn{4}{|l|}{ COPD } \\
\hline No & $160.7(114.7)(149.4 ; 172.0)$ & 399 & 0.001 \\
\hline GOLD I & 185.8 (115.9) (168.9; 202.8) & 183 & \\
\hline GOLD ॥ & $197.4(133.4)(173.3 ; 221.5)$ & 120 & \\
\hline GOLD III/IV & $227.0(158.0)(157.0 ; 297.1)$ & 22 & \\
\hline \multicolumn{4}{|l|}{ DLCO } \\
\hline$>80 \%$ & $170.8(118.5)(160.8 ; 180.8)$ & 545 & 0.202 \\
\hline$<80 \%$ & $184.2(116.9)(166.2 ; 202.3)$ & 163 & \\
\hline \multicolumn{4}{|l|}{ Exacerbations } \\
\hline 0 & $173.5(119.2)(164.4 ; 182.5)$ & 667 & 0.222 \\
\hline 1 or more & $195.0(137.1)(158.6 ; 231.4)$ & 57 & \\
\hline \multicolumn{4}{|l|}{ YPAS score } \\
\hline$<51$ sedentary & $180.3(122.1)(168.5 ; 192.0)$ & 416 & 0.207 \\
\hline$\geq 51$ non-sedentary & $169.2(118.5)(155.6 ; 182.7)$ & 295 & \\
\hline \multicolumn{4}{|l|}{ Emphysema } \\
\hline $0-10 \%$ & $173.0(123.7)(161.9 ; 184.1)$ & 480 & 0.084 \\
\hline$>10 \%$ & $190.3(130.5)(167.9 ; 212.8)$ & 132 & \\
\hline \multicolumn{4}{|c|}{ Airway Wall thickness (Primary Bronchi) } \\
\hline $0-20 \%$ & $179.9(124.3)(168.9 ; 191.0)$ & 485 & 0.071 \\
\hline$>20 \%$ & $164.4(128.4)(141.9 ; 187.0)$ & 127 & \\
\hline \multicolumn{4}{|c|}{ Airway Wall thickness (Secondary Bronchi) } \\
\hline $0-30 \%$ & $173.9(119.5)(163.3 ; 184.5)$ & 489 & 0.192 \\
\hline$>30 \%$ & $190.4(146.0)(164.2 ; 216.7)$ & 121 & \\
\hline
\end{tabular}

$B M I$ body mass index, GOLD Global Initiative for Obstructive Lung Disease, COPD chronic obstructive pulmonary disease, YPAS Yale Physical Activity Questionnaire, $D L C O$ diffusion capacity of the lung for carbon monoxide, $C I$ confidence interval, $S D$ standard deviation of individuals with counts $>300$ eosinophils $/ \mu \mathrm{L}$, being clearly higher than the 192 cells/ $\mu \mathrm{L}$ observed in our study with only $16 \%$ with $\mathrm{BEC}>300$ cells $/ \mu \mathrm{L}$. Similarly, in other Spanish cohorts, Cosio et al. [31] found a mean BEC of 240 cells/ $\mu \mathrm{L}$ in a sample of $706 \mathrm{COPD}$ patients without asthma-COPD overlap, and SolerCataluña et al. [8] reported a mean BEC of 256 cells $/ \mu \mathrm{L}$ in 233 COPD patients, $38.2 \%$ with $\geq 300$ eosinophils/ $\mu \mathrm{L}$, while the mean BEC in asthmatic patients was 402 cells $/ \mu \mathrm{L}$. These higher values may be explained by the different characteristics of the participants, since the subjects in these studies had diagnosed COPD with a mean FEV1(\%) of between 57 and $64 \%$, and $74 \%$ to $85 \%$ were men $[5,8,30]$ compared with a mean $\mathrm{FEV}_{1}(\%)$ of $82 \%$ and $56 \%$ males in our population. Actually, some of these characteristics have been associated with BEC; in our study, male sex, active smoking, previous history of asthma and impaired $\mathrm{FEV}_{1}(\%)$ were significantly and independently associated with a higher BEC. Moreover, in previous studies, male sex [16, 17], active smoking $[17,18]$ and asthma diagnosis [15, 17] have been described as being associated with a higher BEC. Other factors associated with increased eosinophils described in large database study are: age $<18$ years, positive skin prick test, atopy, a positive bronchodilator test, metabolic syndrome and obesity $[16,17]$. Our study found not only a significant difference in BEC between COPD and non-COPD individuals, but also an increase in BEC from non-COPD to GOLD stage III/IV COPD, and similarly, a significant negative correlation between eosinophils and $\mathrm{FEV}_{1}(\%)$ indicating higher levels in more severe disease.

Interestingly, we did not observe any significant association between blood eosinophils and exacerbations or ICS treatment, probably due to the characteristics of our population which was mainly made up of mild and untreated patients. Our results concur with those of a previous large database study in patients at low risk of exacerbations in Primary Care that did not observe any influence of treatment with ICS on BEC, and no association was found between blood eosinophils and the frequency of exacerbations [5].

Blood eosinophils were not associated with percent airway wall area for either the central or peripheral airways. Apparently, there was a trend towards a higher BEC in patients with COPD and more emphysema on $\mathrm{CT}$, but the differences were not significant. On the contrary, Papaioannou et al. [32] found that emphysema was associated with low blood eosinophil counts in a group of 98 patients with COPD. Again, these differences may be due to the different characteristics of 


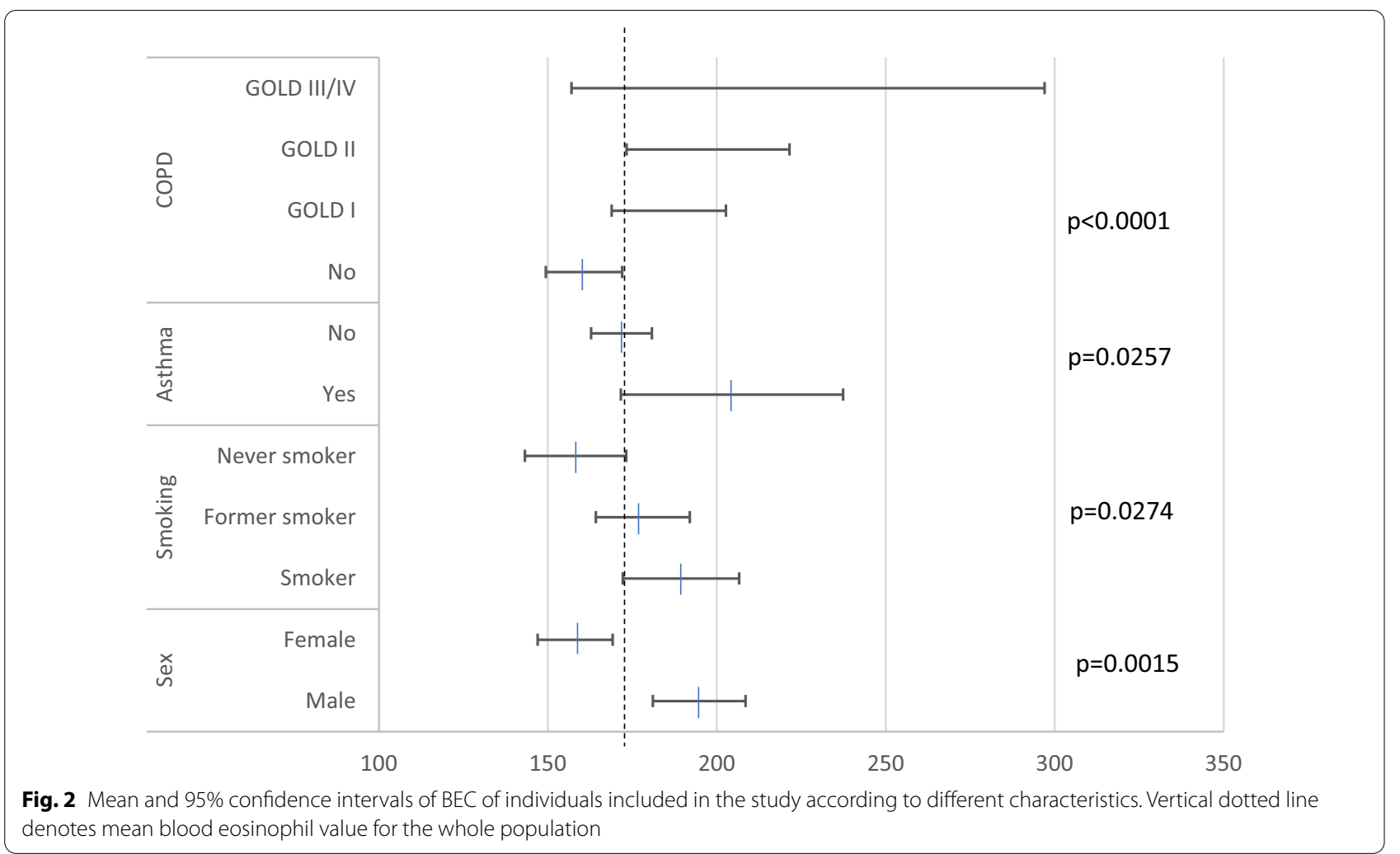

the populations analysed; they defined emphysema as the presence of emphysema lesions in $>15 \%$ of the pulmonary parenchyma, and their emphysema patients had a mean $\mathrm{FEV}_{1}(\%)$ of $43 \%$. In contrast, there was an underrepresentation of patients with moderate and severe COPD in our sample, and the mean percent emphysema area was $10 \%$ in our COPD patients. A recent Canadian study described that patients with COPD and an elevated BEC had thickened central airway walls and a reduction in the total number of visible airways, indicating airway remodelling [33]. More studies are needed to clarify the relationship between BEC and the classic phenotypes of chronic bronchitis and emphysema in COPD.

Our study has several limitations, since it was a population-based study of the general population, patients identified with COPD were predominantly mild, undiagnosed and paucisymptomatic, with underrepresentation of patients with other degrees of severity. However, despite these characteristics, there were clear and significant differences in their characteristics compared with non-COPD individuals, including a significantly higher concentration of blood eosinophils. The cross-sectional design did not allow evaluation of the possible prognostic value of $\mathrm{BEC}$ for outcomes such as exacerbations. However, the design of the study had the strength to allow the analysis of an unselected population of COPD and nonCOPD individuals from all geographic areas of Spain. Finally, we did not systematically assess the presence of possible causes of hypereosinophilia, although they have a low prevalence in the general population.

\section{Conclusions}

The results of our population-based study provide an estimate of the distribution of eosinophils in the healthy adult population in Spain and has demonstrated that COPD patients, even with milder stages, have a significantly higher BEC. In addition to COPD, male sex, active 
Table 3 Multivariate analysis of the factors associated with the BEC

\begin{tabular}{|c|c|c|c|}
\hline \multirow[t]{2}{*}{ Parameter } & \multirow{2}{*}{$\begin{array}{l}\text { Univariate } \\
P \text { value }\end{array}$} & \multicolumn{2}{|l|}{ Multivariate } \\
\hline & & Estimate (standard error) & $P$ value \\
\hline Intercept & & $208.09(31.01)$ & $<0.0001$ \\
\hline Age (years) & 0.4555 & & \\
\hline \multicolumn{4}{|l|}{ Sex } \\
\hline Female & Reference & Reference & \\
\hline Male & $<0.0001$ & $30.98(10.65)$ & 0.0038 \\
\hline BMI $\left(\mathrm{kg} / \mathrm{m}^{2}\right)$ & 0.8615 & & \\
\hline \multicolumn{4}{|l|}{ Smoking } \\
\hline Never smoker & Reference & Reference & \\
\hline Former smoker & 0.0620 & $10.97(12.73)$ & 0.3892 \\
\hline Active smoker & 0.0081 & $31.21(13.68)$ & 0.0229 \\
\hline \multicolumn{4}{|l|}{ Asthma } \\
\hline No & Reference & Reference & \\
\hline Yes & 0.0274 & $36.91(16.83)$ & 0.0288 \\
\hline CAT score & 0.1159 & & \\
\hline FEV1 (\%) & 0.0002 & $-0.53(0.28)$ & 0.0543 \\
\hline DLCO (\%) & 0.0474 & & \\
\hline YPAS score & 0.0493 & & \\
\hline $6 \mathrm{MWD}, \mathrm{m}$ & 0.3057 & & \\
\hline Exacerbations last year & 0.0331 & & \\
\hline \multicolumn{4}{|l|}{ COPD } \\
\hline No & Reference & & \\
\hline Yes & 0.0003 & & \\
\hline Treatment with ICS & 0.0099 & & \\
\hline Platelets, cells/ $\mu \mid$ & 0.1026 & & \\
\hline Fibrinogen (g/L) & 0.9357 & & \\
\hline CRP $(\mathrm{mg} / \mathrm{dL})$ & 0.0831 & & \\
\hline Total emphysema volume (\%) & 0.0082 & $0.94(0.51)$ & 0.0660 \\
\hline \% Airway wall area (Primary Bronchi) & 0.4094 & & \\
\hline \% Airway wall area (Secondary bronchi) & 0.1527 & & \\
\hline
\end{tabular}

$B M I$ body mass index, CAT COPD assessment test, FEV1 forced expiratory volume in the first second, FVC forced vital capacity, DLCO diffusion capacity of the lung for carbon monoxide, 6MWD 6-min walk distance, YPAS Yale Physical Activity Questionnaire, CRP C-reactive protein. Values in bold are statistically significant. R-Square $=0.067$

smoking, the presence of asthma and a worse $\mathrm{FEV}_{1}(\%)$ are significantly associated with a higher BEC.

\section{Abbreviations}

ATS: American Thoracic Society; BEC: Blood eosinophil count; CAT: COPD assessment test; COPD: Chronic obstructive pulmonary disease; $\mathrm{CT}$ : Computed tomography; CRP: C-reactive protein; DLCO: Diffusing capacity of the lung for carbon monoxide; EPISCAN: Epidemiological study of COPD in Spain; ERS: European Respiratory Society; FEV1: Forced expiratory volume in $1 \mathrm{~s}$; FVC: Forced vital capacity; GOLD: Global initiative for obstructive lung disease; ICS: Inhaled corticosteroids; SAS: Statistical analysis system; SD: Standard deviation; 6MWT: Six-minute walking test; UK: United Kingdom; YPAD: Yale Physical Activity Questionnaire.

\section{Acknowledgements}

The collaboration of Monica Sarmiento and Neus Canal of IQVIA, and Carolina Peña and José Julio Jiménez from GSK is explicitly acknowledged. The following investigators have participated in EPI SCAN II: Scientific Committee: Inmaculada Alfageme, Pilar de Lucas, Julio Ancochea, Marc Miravitlles, Juan
José Soler-Cataluña, Francisco García-Río, Ciro Casanova, José Miguel Rodríguez González-Moro, Borja G. Cosio, Guadalupe Sánchez, and Joan B Soriano. Principal Investigators, collaborators and participating centres: MADRID: $\mathrm{H}$. La Princesa, Julio Ancochea Bermudez (IP) / Elena García Castillo / Claudia Valenzuela / Joan B Soriano. CASTILLA LEÓN: H. U. de Burgos, Ana Pueyo Bastida (IP) / Lourdes Lázaro Asegurado / Luis Rodríguez Pascual / Ma José Mora. ARAGÓN: H. Gral. San Jorge, Luis Borderias Clau (IP) / Lourdes Arizón Mendoza / Sandra García. EXTREMADURA: H. San Pedro de Alcántara, Juan Antonio Riesco Miranda (IP) / Julián Grande Gutiérrez / Jesús Agustín Manzano / Manuel Agustín Sojo González. CASTILLA LEÓN: H. Clínico U. de Salamanca, Miguel Barrueco Ferrero (IP) / Milagros Rosales. GALICIA: H. Álvaro Cunqueiro, José Alberto Fernández Villar (IP) / Cristina Represas / Ana Priegue / Isabel Portela Ferreño / Cecilia Mouronte Roibás / Sara Fernández García. I. BALEARES: H. Son Espases, Borja G Cosío (IP) / Rocío Cordova Díaz / Nuria Toledo Pons / Margalida Llabrés. ARAGÓN: H. U. Miguel Servet, José María Marín Trigo (IP) / Marta Forner / Begoña Gallego / Pablo Cubero / Elisabet Vera. C. VALENCIANA: H. Arnau de Vilanova (Valencia), Juan José Soler Cataluña (IP) / Ma Begoña Picurelli Albero / Noelia González García. ANDALUCíA: H. Virgen de la Macarena, Agustín Valido Morales (IP) / Carolina Panadero / Cristina Benito Bernáldez/Laura Martín -Bejarano y Maria Velar. MURCIA: H. Gral. U. Santa Lucía (Cartagena), Antonio Santa Cruz Siminiani (IP) / Carlos Castillo 
Quintanilla / Rocío Ibáñez Meléndez / José Javier Martínez Garcerán / Desirée Lozano Vicente / Pedro García Torres / Maria del Mar Valdivia. NAVARRA: Clínica Universidad de Navarra, Juan Pablo de Torres Tajes (IP) / Montserrat Cizur Girones / Carmen Labiano Turrillas. LA RIOJA: H. de San Pedro (Logroño), Carlos Ruiz Martínez (IP)/ Elena Hernando / Elvira Alfaro / José Manuel García / Jorge Lázaro. PAÍS VASCO: H. Santiago Apóstol (H. Txagorritxu), David Bravo (IP) /Laura Hidalgo / Silvia Francisco Terreros / Iñaki Zorrilla / Ainara Alonso Colmenero. ASTURIAS: H. Central de Asturias, Cristina Martínez González (IP) / Susana Margon/ Rosirys Guzman Taveras/ Ramón Fernández / Alicia Álvarez. CANTABRIA: H. de Valdecilla, José Ramón Agüero Balbín (IP) / Juan Agüero Calvo. CATALUÑA: H. U. Vall d'Hebron, Jaume Ferrer Sancho (IP) / Esther Rodríguez González/ Eduardo Loeb. CASTILLA LA MANCHA: H. U. de Guadalajara, José Luis Izquierdo Alonso (IP) / Ma Antonia Rodríguez García. I. CANARIAS: H. U. de Tenerife, Juan Abreu González (IP)/ Candelaria Martín García/ Rebeca Muñoz/ Haydée Martín García. ASTURIAS: H. U. de San Agustín (Avilés), Miguel Angel Martínez Muñiz (IP) / Andrés Avelino Sánchez Antuña / Jesús Allende González / Jose Antonio Gullón Blanco / Fernando José Alvarez Navascues / Manuel Angel Villanueva Montes / María Rodríguez Pericacho / Concepción Rodríguez García / Juan Diego Alvarez Mavárez.

\section{Authors' contributions}

The study concept and design: MM, JJS-C, JBS, FG-R, PL, IA, CC, JMG-M, GS, JA, BGC. The acquisition of the data: JJS-C, JA, BGC. Analysis or interpretation of the data: MM, JJS-C, JBS, BGC. The drafting of the manuscript: MM. Critical revision and approval for submission: MM, JJS-C, JBS, FG-R, PL, IA, CC, JMG-M, GS, JA, BGC. All authors read and approved the final manuscript.

\section{Funding}

The EPI SCAN II study was funded by an unrestricted grant from GlaxoSmithKline.

\section{Availability of data and materials}

Information on the GSK data sharing commitments and requesting access to anonymized individual participant data and associated documents can be found at www.clinicalstudydatarequest.com.

\section{Declarations}

\section{Ethics approval and consent to participate}

The study was approved by the ethics committees of each of the participating centres, and all participants provided informed consent.

\section{Consent for publication}

Not applicable.

\section{Competing interests}

Marc Miravitlles has received speaker or consulting fees from AstraZeneca, Bial, Boehringer Ingelheim, Chiesi, Cipla, CSL Behring, Laboratorios Esteve, Gebro Pharma, Kamada, GlaxoSmithKline, Grifols, Menarini, Mereo Biopharma, Novartis, pH Pharma, Palobiofarma SL, Rovi, TEVA, Spin Therapeutics, Verona Pharma and Zambon, and research grants from Grifols. Juan José Soler-Cataluña has received speaker fees from AstraZeneca, Bial, Boehringer Ingelheim, Chiesi, Esteve, Ferrer, GlaxoSmithKline, Menarini, Novartis and Teva, and and consulting fees from AstraZeneca, Bial, Boehringer Ingelheim, GlaxoSmithKline, Ferrer and Novartis. Francisco García-Río has received speaker or consulting fees from AstraZeneca, Boehringer Ingelheim, Chiesi, GlaxoSmithKline, Menarini, Novartis, Pfizer and Rovi, and research grants from Chiesi, Esteve, Gebro Pharma, GlaxoSmithKline, Menarini and TEVA. Julio Ancochea has received speaker or consulting fees from Actelion, Air Liquide, Almirall, AstraZeneca, Boehringer Ingelheim, Carburos Médica, Chiesi, Faes Farma, Ferrer, GlaxoSmithKline, InterMune, Linde Healthcare, Menarini, MSD, Mundipharma, Novartis, Pfizer, Roche, Rovi, Sandoz, Takeda y Teva. Inmaculada Alfageme has no conflicto of interest. Ciro Casanova has received speaker or consulting fees from AstraZeneca, Bial, Boehringer Ingelheim, Chiesi, GlaxoSmithKline, Menarini, Novartis, and research grants from GlaxoSmithKline, Menarini and AstraZeneca. M. Guadalupe Sánches-Herrero is a GSK employee within the Medical Department. Borja G Cosio has received speaker or consulting fees from AstraZeneca, Boehringer Ingelheim, Chiesi, GlaxoSmithKline, Menarini, Novartis, Sanofi, TEVA, and research grants from Menarini, AstraZeneca and Boehringer-Ingelheim.

\section{Author details}

1Pneumology Department, Hospital Universitari Vall d'Hebron/Vall d'Hebron Institut de Recerca (VHIR), Vall d'Hebron Barcelona Hospital Campus, P. Vall d'Hebron 119-129, 08035 Barcelona, Spain. ${ }^{2}$ CIBER de Enfermedades Respiratorias (CIBERES), Instituto de Salud Carlos III (ISCIII), Madrid, Spain. ${ }^{3}$ Servicio de Neumología, Hospital Arnau de Vilanova-Lliria, Universidad de la Laguna, Valencia, Spain. ${ }^{4}$ Servicio de Neumología, Hospital Universitario la Princesa, Universidad Autónoma de Madrid, Madrid, Spain. ${ }^{5}$ Servicio de Neumología, Hospital Universitario la Paz-IdiPAZ, Madrid, Spain. '5ervicio de Neumología, Hospital General Gregorio Marañon, Madrid, Spain. ${ }^{7}$ Unidad de Gestión Clínica de Neumología, Hospital Universitario Virgen de Valme, Universidad de Sevilla, Sevilla, Spain. ${ }^{8}$ Servicio de Neumología, Hospital Universitario Nuestra Señora de Candelaria, Tenerife, Spain. ${ }^{9}$ Servicio de Neumología, Hospital Universitario "Príncipe de Asturias", Alcalá de Henares, Universidad de Alcalá, Madrid, Spain. ${ }^{10}$ Departamento Médico, GSK, Tres Cantos, Madrid, Spain. ${ }^{11}$ Servicio de Neumología, Hospital Universitario Son Espases-IdISBa, Palma de Mallorca, Spain.

Received: 1 October 2021 Accepted: 20 February 2022

Published online: 05 March 2022

\section{References}

1. Cosio BG, Soriano JB, López-Campos JL, Calle M, Soler JJ, de Torres JP, et al. Distribution and outcomes of a phenotype-based Approach to guide COPD management: results from the CHAIN cohort. PLOS ONE. 2016;11(9):e0160770

2. Miravitlles M, Calle M, Soler-Cataluña JJ. Clinical phenotypes of COPD. Identification, definition and implications for guidelines. Arch Bronconeumol. 2012;48:86-98.

3. Yun JH, Lamb A, Chase R, Singh D, Parker MM, Saferali A, et al. Blood eosinophil count thresholds and exacerbations in patients with chronic obstructive pulmonary disease. J Allergy Clin Immunol. 2018;141(6):2037-47.

4. Kerkhof M, Chaudhry I, Pavord ID, Miravitlles M, Kook Rhee C, Halpin DMG, et al. Blood eosinophil count predicts treatment failure and hospital readmission for COPD. ERJ Open Res. 2020;6(4):00188-2020.

5. Miravitlles M, Monteagudo M, Solntseva I, Alcázar B. Blood eosinophil counts and their variability and risk of exacerbations in COPD: a population-based study. Arch Bronconeumol. 2021;57:13-20.

6. Golpe R, Dacal D, Sanjuán-López P, Martín-Robles I, Pérez-de-Llano LA. Plasma eosinophil count and patient-centered events in chronic obstructive pulmonary disease in real-life clinical practice. Arch Bronconeumol. 2020;56(2):129-30.

7. Singh D, Wedzicha JA, Siddiqui S, de la Hoz A, Xue W, Magnussen H, et al. Blood eosinophils as a biomarker of future COPD exacerbation risk: pooled data from 11 clinical trials. Respir Res. 2020;21(1):240.

8. Soler-Cataluña JJ, Novella L, Soler C, Nieto ML, Esteban V, Sánchez-Toril F, et al. Clinical characteristics and risk of exacerbations associated with different diagnostic criteria of asthma-COPD overlap. Arch Bronconeumol. 2020:56(5):282-90.

9. Pavord ID, Lettis S, Locantore N, Pascoe S, Jones PW, Wedzicha JA, et al. Blood eosinophils and inhaled corticosteroid/long-acting $\beta$-2 agonist efficacy in COPD. Thorax. 2016;71:118-25.

10. Brusselle G, Pavord ID, Landis S, Pascoe S, Lettis S, Morjaria N, et al. Blood eosinophil levels as a biomarker in COPD. Respir Med. 2018;138:21-31.

11. Singh D, Bafadhel $M$, Brightling CE, Sciurba FC, Curtis $J$, Martinez FJ, et al. Blood eosinophil counts in clinical trials for chronic obstructive pulmonary disease. Am J Respir Crit Care Med. 2020;202(5):660-71.

12. Global Strategy For The Diagnosis, Management, And Prevention Of Chronic Obstructive Pulmonary Disease. 2021 Report. https://goldcopd. org/wp-content/uploads/2020/11/GOLD-REPORT-2021-v1.1-25Nov20_ WMV.pdf [Accessed May 16th, 2021.

13. Miravitlles M, Calle M, Molina J, Almagro P, Gómez JT, Trigueros JA, et al. Spanish COPD Guidelines (GesEPOC) 2021: updated pharmacological treatment of stable COPD. Arch Bronconeumol 2022;58:69-81. https:// doi.org/10.1016/j.arbres.2021.03.005.

14. Vogelmeier CF, Kostikas K, Fang J, Tian H, Jones B, Morgan CL, et al. Evaluation of exacerbations and blood eosinophils in UK and US COPD populations. Respir Res. 2019;20(1):178. 
15. Landis S, Suruki R, Maskell J, Bornar K, Hilton E, Compton C. Demographic and clinical characteristics of COPD patients at different blood eosinophil levels in the UK clinical practice research datalink. COPD. 2018;15:177-84.

16. Çolak Y, Afzal S, Nordestgaard BG, Marott JL, Lange P. Combined value of exhaled nitric oxide and blood eosinophils in chronic airway disease: the Copenhagen General Population Study. Eur Respir J. 2018;52(2):1800616.

17. Hartl S, Breyer MK, Burghuber OC, Ofenheimer A, Schrott A, Urban MH, et al. Blood eosinophil count in the general population: typical values and potential confounders. Eur Respir J. 2020;55(5):1901874.

18. Kolsum U, Southworth T, Jackson N, Singh D. Blood eosinophil counts in COPD patients compared to controls. Eur Respir J. 2019;54(4):1900633.

19. Alfageme I, de Lucas P, Ancochea J, Miravitlles M, Soler-Cataluña JJ, García-Río F, et al. 10 Years After EPISCAN: a new study on the prevalence of COPD in Spain - a summary of the EPISCAN II protocol. Arch Bronconeumol. 2019;55:38-47.

20. Soriano JB, Alfageme I, Miravitlles M, de Lucas P, Soler-Cataluña JJ, GarcíaRío F, et al. Prevalence and Determinants of COPD in Spain: EPISCAN II. Arch Bronconeumol. 2021;57:61-9.

21. Miller MR, Hankinson J, Brusasco V, Burgos F, Casaburi R, Coates A, et al. ATS/ERS Task Force. Standardization of spirometry. Eur Respir J. 2005;26:319-38.

22. Quanjer PH, Stanojevic S, Cole TJ, Baur X, Hall GL, Culver BH, ERS Global Lung Function Initiative, et al. Multi-ethnic reference values for spirometry for the 3-95-yr age range: the global lung function 2012 equations. Eur Respir J. 2012;40:1324-43.

23. De Abajo S, Larriba R, Márquez $S$. Validity and reliability of the Yale Physical Activity Survey in Spanish elderly. J Sports Med Phys Fitness. 2001;41:479-85

24. Donaire-González D, Gimeno-Santos E, Serra I, Roca J, Balcells E, Rodríguez E, et al. Validación del cuestionario de actividad física de Yale en pacientes con enfermedad pulmonar obstructiva crónica. Arch Bronconeumol. 2011;47:552-60.

25. American Thoracic Society ATS Statement: Guidelines for the Six-Minute Walk Test. Am J Respir Crit Care Med 2002; 166: 111-117.

26. Maclntyre N, Crapo RO, Viegi G, Johnson DC, van der Grinten CPM, Brusasco V, et al. Standardisation of the single-breath determination of carbon monoxide uptake in the lung. Eur Respir J. 2005;26:720-35.

27. Owrangi AM, Etemad-Rezai R, McCormack DG, Cunningham IA, Parraga G. Computed tomography density histogram analysis to evaluate pulmonary emphysema in ex-smokers. Acad Radiol. 2013;20:537-45.

28. Galban C, Han M, Boes J, Chughtai K, Meyer C, Johnson T, et al. Computed tomography-based biomarker provides unique signature for diagnosis of COPD phenotypes and disease progression. Nat Med. 2012;18:1711-5.

29. Nambu A, Zach J, Schroeder J, Jin G, Kim SS, Kim Yl, et al. Quantitative computed tomography measurements to evaluate airway disease in chronic obstructive pulmonary disease: relationship to physiological measurements, clinical index and visual assessment of airway disease. Eur J Radiol. 2016;85:2144-51.

30. Bafadhel M, Pavord ID, Russell REK. Eosinophils in COPD: just another biomarker? Lancet Respir Med. 2017;5(9):747-59.

31. Cosio BG, Soriano JB, López-Campos JL, Calle-Rubio M, Soler-Cataluna $\mathrm{JJ}$, de Torres JP, et al. Defining the asthma-COPD overlap syndrome in a COPD cohort. Chest. 2016;149(1):45-52.

32. Papaioannou Al, Kostikas K, Papaporfyriou A, Angelakis L, Papathanasiou E, Hillas $G$, et al. Emphysematous phenotype is characterized by low blood eosinophils: a cross-sectional study. COPD. 2017;14:635-40.

33. Tan WC, Bourbeau J, Nadeau G, Wang W, Barnes N, Landis SH, et al. High eosinophil counts predict decline in FEV1: results from the CanCOLD study. Eur Respir J. 2021;57(5):2000838.

\section{Publisher's Note}

Springer Nature remains neutral with regard to jurisdictional claims in published maps and institutional affiliations. 